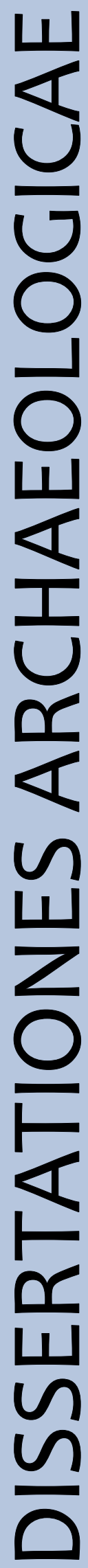

ex Instituto Archaeologico Universitatis de Rolando Eötvös nominatae
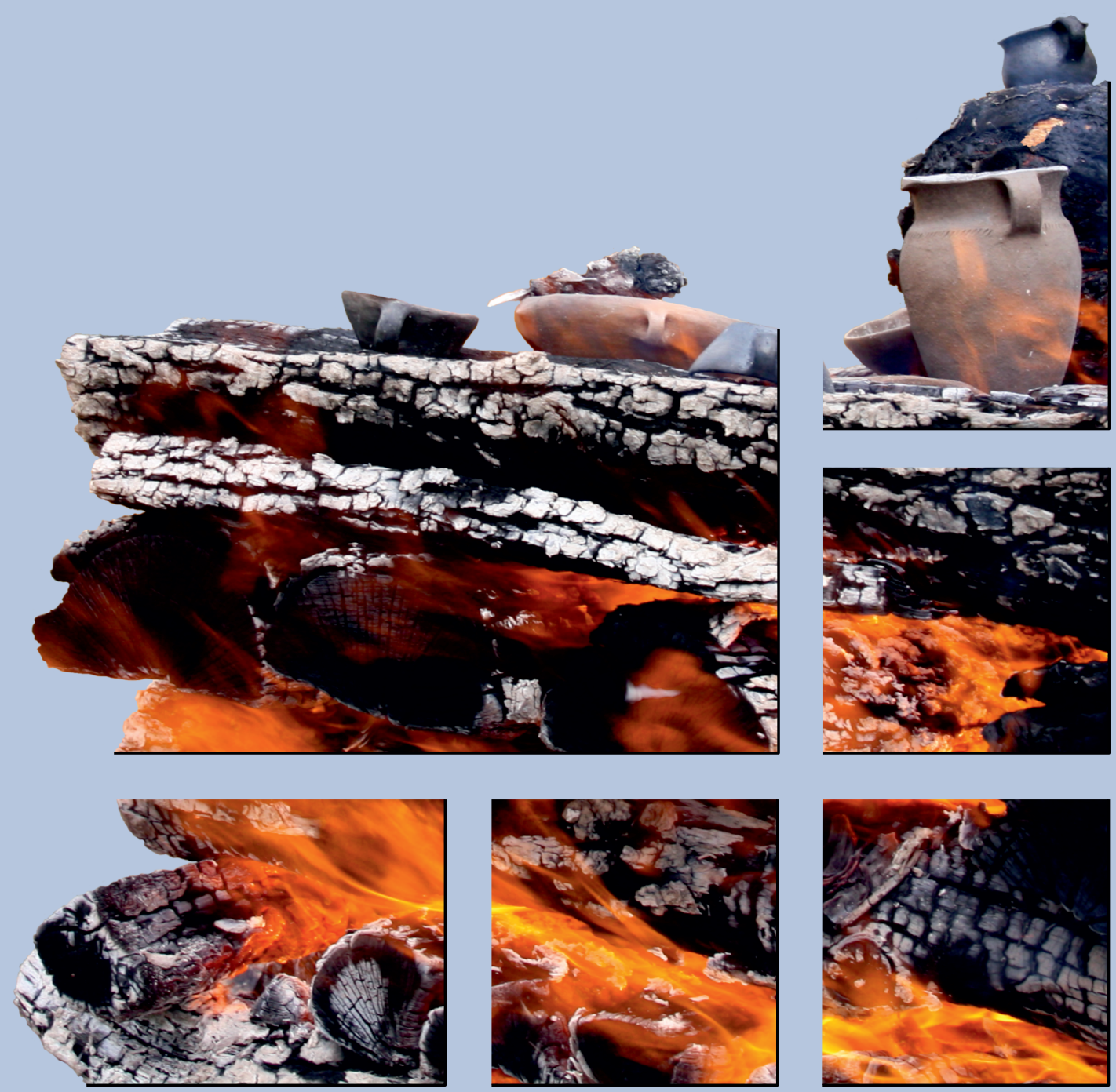

$$
\text { Ser。 3. No } 0_{0} \sigma_{0} \mid 2018
$$




\section{Dissertationes Archaeologicae ex Instituto Archaeologico}

Universitatis de Rolando Eötvös nominatae Ser. 3. No. 6.

Budapest 2018 


\section{Dissertationes Archaeologicae ex Instituto Archaeologico}

Universitatis de Rolando Eötvös nominatae Ser. 3. No. 6.

Editor-in-chief:

DÁvid BARTUS

Editorial board:

LÁsZló BARTOSIEWICZ

LÁSZLÓ BORHY

ZOLTÁN CZAJLIK

ISTVÁN FELD

GÁBOR KALLA

PÁL RACZKY

MiKLÓS SZABÓ

Tivadar Vida

Technical editor:

GÁBOR VÁcZI

Proofreading:

ZsófIA KondÉ

SzILVIA BARTUS-SzÖLLősI

Aviable online at http://dissarch.elte.hu

Contact: dissarch@btk.elte.hu

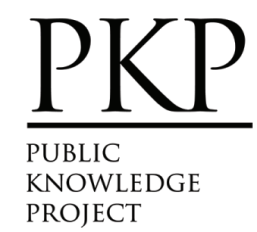

๑ E Eötvös Loránd University, Institute of Archaeological Sciences

Layout and cover design: Gábor Váczi

Budapest 2018 


\section{CONTENTS}

Zsolt Mester

In memoriam facques Tixier (1925-2018)

\section{ARTICLES}

Katalin SEBőK

On the possibilities of interpreting Neolithic pottery - Az újkökori kerámia értelmezési lehetőségeiről

András FüZESI - Pál RACZKY

Öcsöd-Kováshalom. Potscape of a Late Neolithic site in the Tisza region

Katalin SEBőK - Norbert FARAgó

Theory into practice: basic connections and stylistic affiliations of the Late Neolithic settlement at Pusztataskony-Ledence 1

Eszter Solnay

Early Copper Age Graves from Polgár-Nagy-Kasziba

László GuCsi - Nóra Szabó

Examination and possible interpretations of a Middle Bronze Age structured deposition

Kristóf FÜLÖP

Why is it so rare and random to find pyre sites? Two cremation experiments to understand the characteristics of pyre sites and their investigational possibilities

Gábor János TARBAY

"Looted Warriors" from Eastern Europe

Péter MogYoRós

Pre-Scythian burial in Tiszakürt

Szilvia JoHÁczi

A New Method in the Attribution? Attempts of the Employment of Geometric Morphometrics in the Attribution of Late Archaic Attic Lekythoi 
The Roman aqueduct of Brigetio

Lajos JuHÁsz

A republican plated denarius from Aquincum

Barbara HAJDU

Terra sigillata from the territory of the civil town of Brigetio

Krisztina HoppÁL - István VIDA - Shinatria AdHityatAma - Lu Yahui 461

'All that glitters is not Roman'. Roman coins discovered in East Java, Indonesia.

A study on new data with an overview on other coins discovered beyond India

\section{FIELD REPORTS}

Zsolt MESTER - Ferenc CSERPÁK - Norbert FARAGÓ

Preliminary report on the excavation at Andornaktálya-Marinka in 2018

Kristóf FÜLÖP - Denisa M. LÖNHARDT - Nóra SZABÓ - Gábor VÁcZI

Preliminary report on the excavation of the site Tiszakürt-Zsilke-tanya

Bence Simon - Szilvia JohÁcZI - Zita KIS

Short report on a rescue excavation of a prehistoric and Árpádian Age site near Tura

(Pest County, Hungary)

Zoltán CzAJlik - Katalin NovinszKi-Groma - László RupNIK - András BöDőcs - et al. 527

Archaeological investigations on the Süttö plateau in 2018

Dávid BARTus - László BORHY - Szilvia JoHÁczi - Emese SzÁMADó

Short report on the excavations in the legionary fortress of Brigetio (2017-2018)

Bence Simon - Szilvia JoháczI

Short report on the rescue excavations in the Roman Age Barbaricum near Abony

(Pest County, Hungary)

Szabolcs Balázs NAGY

Recent excavations at the medieval castle of Bánd 


\section{Thesis Abstracts}

Rita JENEY

Lost Collection from a Lost River: Interpreting Sir Aurel Stein's "Sarasvatī Tour" in the History of South Asian Archaeology

István VIDA

The Chronology of the Marcomannic-Sarmatian wars. The Danubian wars of Marcus Aurelius in the light of numismatics

Zsófia MASEK

Settlement History of the Middle Tisza Region in the $4^{\text {th }}-6^{\text {th }}$ centuries AD.

According to the Evaluation of the Material from Rákóczifalva-Bagi-földek 5-8-8A sites

Alpár Doвоs

Transformations of the human communities in the eastern part of the Carpathian Basin between the middle of the $5^{\text {th }}$ and $7^{\text {th }}$ century. Row-grave cemeteries in Transylvania, Partium and Banat 


\title{
Terra sigillata from the territory of the civil town of Brigetio
}

\author{
BARBARA HAJDU \\ Aquincum Museum \\ Department of Ancient History \\ hajdubarbi91@gmail.com
}

\begin{abstract}
On the territory of the civil town of Brigetio systematic excavations were carried out on regular basis between 1992 and 2016 which resulted in a huge amount of terra sigillata sherds besides the other finds. In this paper I present a few pieces uncommon in Pannonia province as well as those which provide the most relevant data from a chronological viewpoint. Furthermore, these terra sigillata sherds not only provide information about dating but also allow a glimpse into the everyday life and commercial relationships of the civil town.
\end{abstract}

\section{Introduction}

Between 1992 and 2016, systematic excavations were carried out yearly on the territory of the civil town of Brigetio (Fig. 1), during the course of which more than ten thousand terra sigillata sherds came to light. This paper presents the terra sigillata material of the excavation seasons between 2010 and 2016. The reason for choosing this time interval is that during these years many buildings and other archaeological features were revealed which played an important role in the history of Brigetio, therefore the dating of these is essential for the further research of the town.

The examined terra sigillata material is consisting of 6516 sherds. The vessels were imported to Brigetio from the territory of Northern Italy, Gallia, Germania, Raetia, Noricum and Northern Africa. In addition to the variousworkshops, there is also a great diversity of vessel types. The wide range of the terra sigillata sherds suggests extended and complex commercial relationships.

\section{Terra sigillata finds}

In the framework of the present survey, a total amount of 6516 sherds were processed from the excavation seasons between 2010 and 2016 (Tab. 1, Fig. 2). ${ }^{1}$ The research shed light to the far-reaching commercial relationships of Brigetio, according to it, terra sigillata vessels were imported to this town from all around the most important workshops of the Roman Empire.

In chronological order, the oldest terra sigillata vessels which were excavated in Brigetio were made in the Po Valley, situated in the northern part of Italy. These few terra sigillata sherds

1 Highlighting this time-interval from the whole terra sigillata material distorts the results in some ways, but it does not change the proportions of the workshops and it seems to be an efficient way to briefly summarize this ongoing research so far. This reason gave grounds for presenting this narrow segment of the finds. The work on this paper was supported by Hungarian Scientific Research Fund (OTKA 108667). 
(55 pieces, $0.84 \%$ ) are insignificant in a statistical sense but they are important from the viewpoint of the research because these pieces refer to the first phase of the life of the civil town. The percentage of South Gaulish wares in the terra sigillata material is low ( 52 sherds, $0.8 \%$ ), similarly to those from Northern Italy. These can also be dated to the earliest periods of Brigetio. The third largest group of terra sigillata sherds (1490 pieces, 22.87\%) in the assemblage consists of pieces imported from Central Gaul. On the contrary, from the eastern part of Gaul only very few terra sigillata (5 sherds, $0.08 \%$ ) came to Brigetio. The largest number of vessels were imported from Rheinzabern (2512 sherds, 38.57\%), which is quite usual along the Pannonian limes. Also a vast amount of terra sigillata came from Westerndorf (1606 sherds, 24.66\%), while only a few came from its contemporary workshop of Pfaffenhofen (108 sherds, $1.66 \%$ ). Statistically the least significant part of the material consists of only two sherds from North Africa (0.03\%), but despite their low number they provide us with important information about the commercial relationships and are important from a chronological point of view as well.

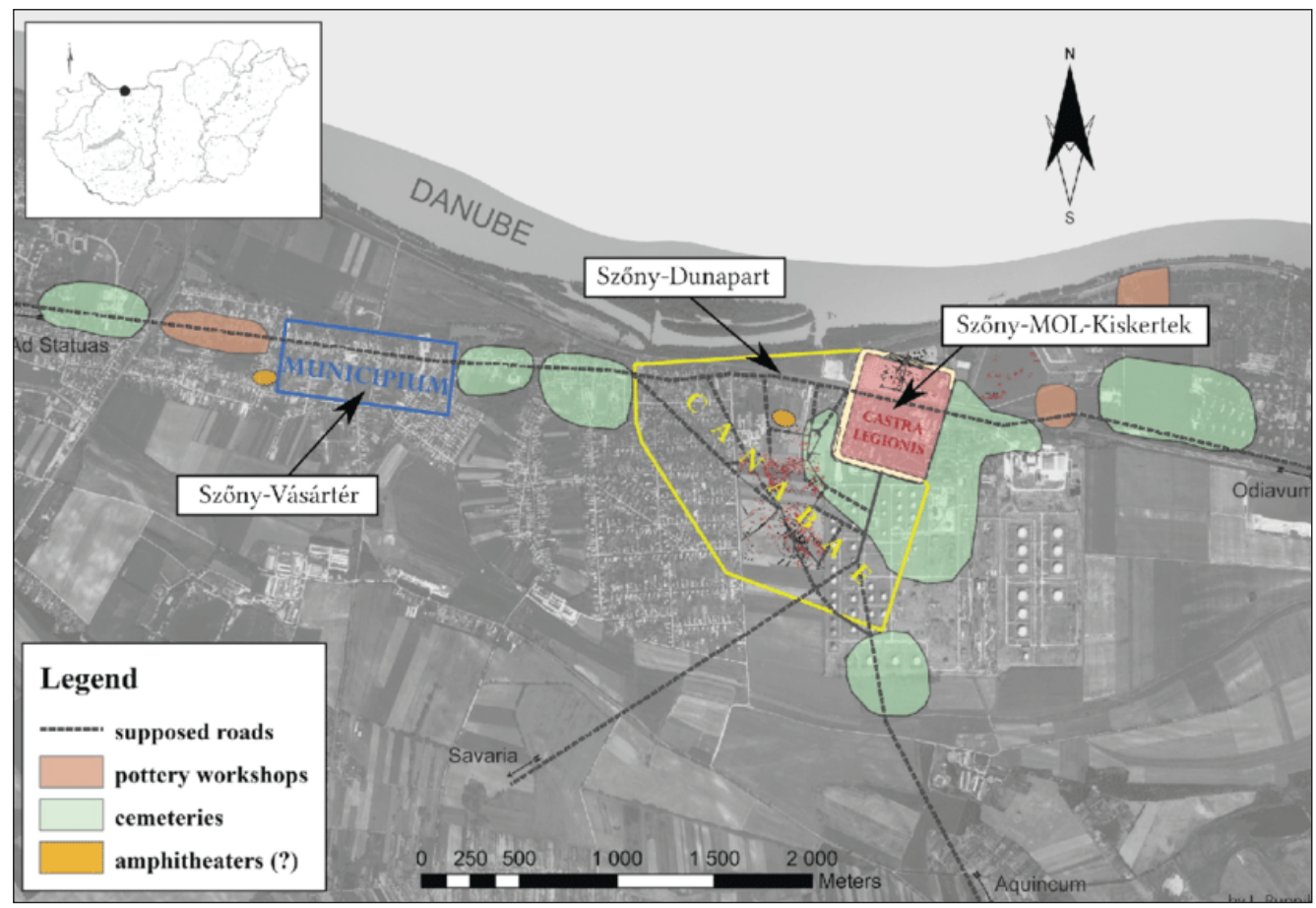

Fig. 1. Map of Brigetio (by László Rupnik, PhD, ELTE).

\section{North Italian terra sigillata}

As mentioned above, the North Italian terra sigillata from the area of the Po Valley are the earliest pieces among the finds. Despite their low number (55 sherds, 0.84\%) (Fig. 2) they are important regarding the first phases of the civil town of Brigetio. The North Italian wares are conspicuously missing from those military camps alongside the Pannonian limes which were in use during the rule of Trajan, ${ }^{2}$ therefore we can assume that in the case of Brigetio their trade has also ceased after Trajan.

In the civil town of Brigetio mainly Consp. 39 and Consp. 43 (Fig. 3.1) types with barbotine-decorated rim (form-group B) were present among the finds. ${ }^{3}$ These types were manufac-

2 GABLER 2001, 117.

3 EtTLINGER et al. 2002, 50. 
tured from the $2^{\text {nd }}$ half of the $1^{\text {st }}$ century AD until the middle of the $2^{\text {nd }}$ century $A D$ in the area of the Po Valley. ${ }^{4}$ The Consp. 39 dishes and the Consp. 43 hemispherical cups were exported to the provinces along the Danube mainly from the Flavian era. These types were imported to Pannonia at the end of this period, especially during the rule of Domitian. ${ }^{5}$ Similarly to Brigetio, the Consp. 39 and Consp. 43 terra sigillata can be observed frequently on other Pannonian archaeological sites, however the number of the vessels is usually low.

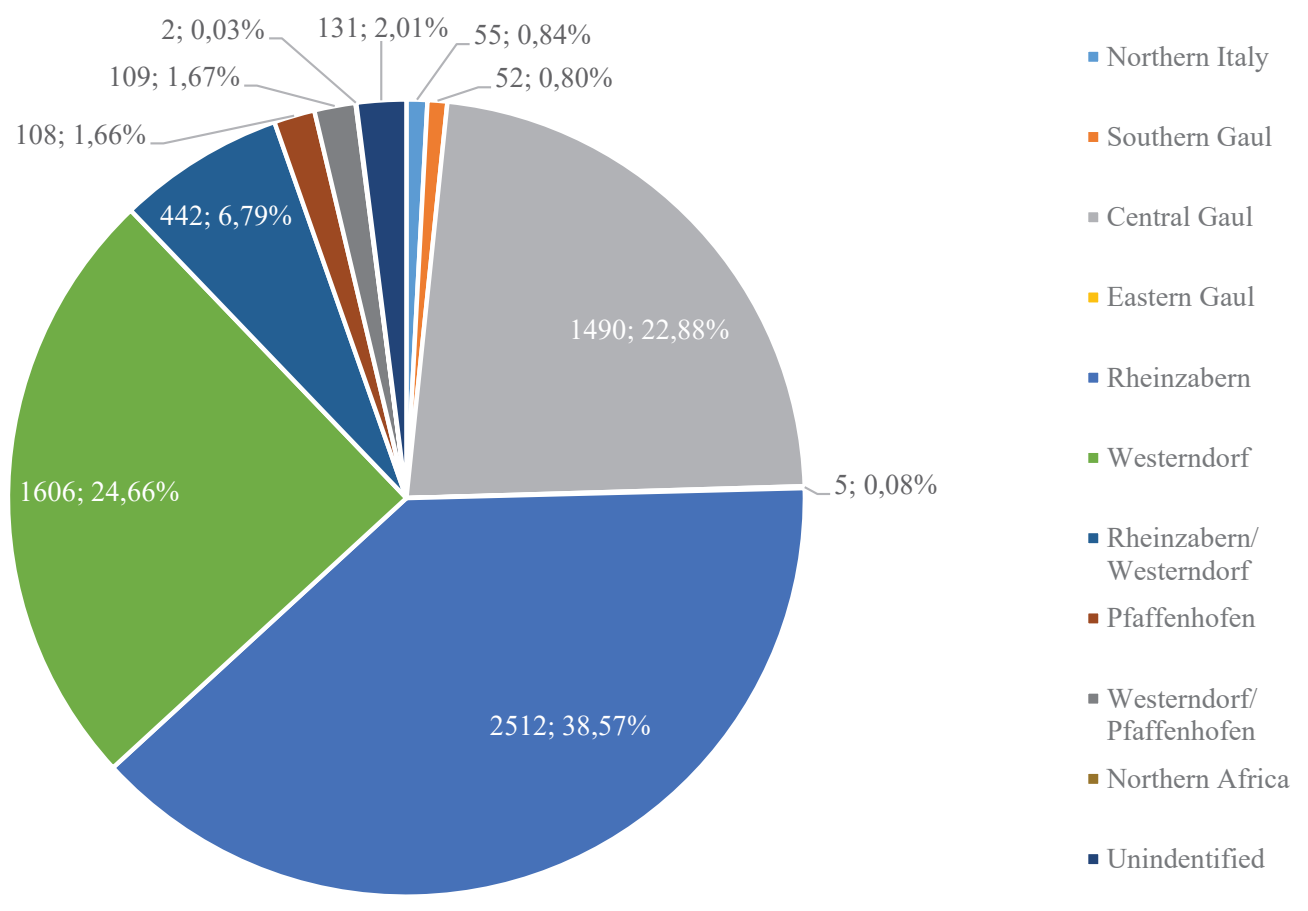

Fig. 2. Distribution of terra sigillata finds according to the workshops.

There are a few sherds of Consp. 41 (Fig. 3.2) dishes with barbotine-decorated rim, belonging to the , D2 form-group, ${ }^{6}$ among the terra sigillata material of the civil town of Brigetio. These vessels were produced from the Flavian era until the middle of the $2^{\text {nd }}$ century $\mathrm{AD}$. Consp. 41 type dishes are quite rare in Brigetio even though they were wide-spread in the provinces along the Danube. ${ }^{7}$

\section{South Gaulish terra sigillata}

In the southern part of Gaul the production of terra sigillata began around the end of the $1^{\text {st }}$ century BC. The earliest products of these workshops mainly followed the Italian traditions but the gradual formation of the characteristic Gaulish vessel types can already be observed. The autonomous manufacturing in Southern Gaul proceeded during the $1^{\text {st }}$ century AD. The typical feature of the South Gaulish relief-decorated bowls was that the decoration was divided into two zones which can be traced back to Italian traditions. The carefully planned and manufactured vessels were decorated with naturalistic motives and mythological scenes. 

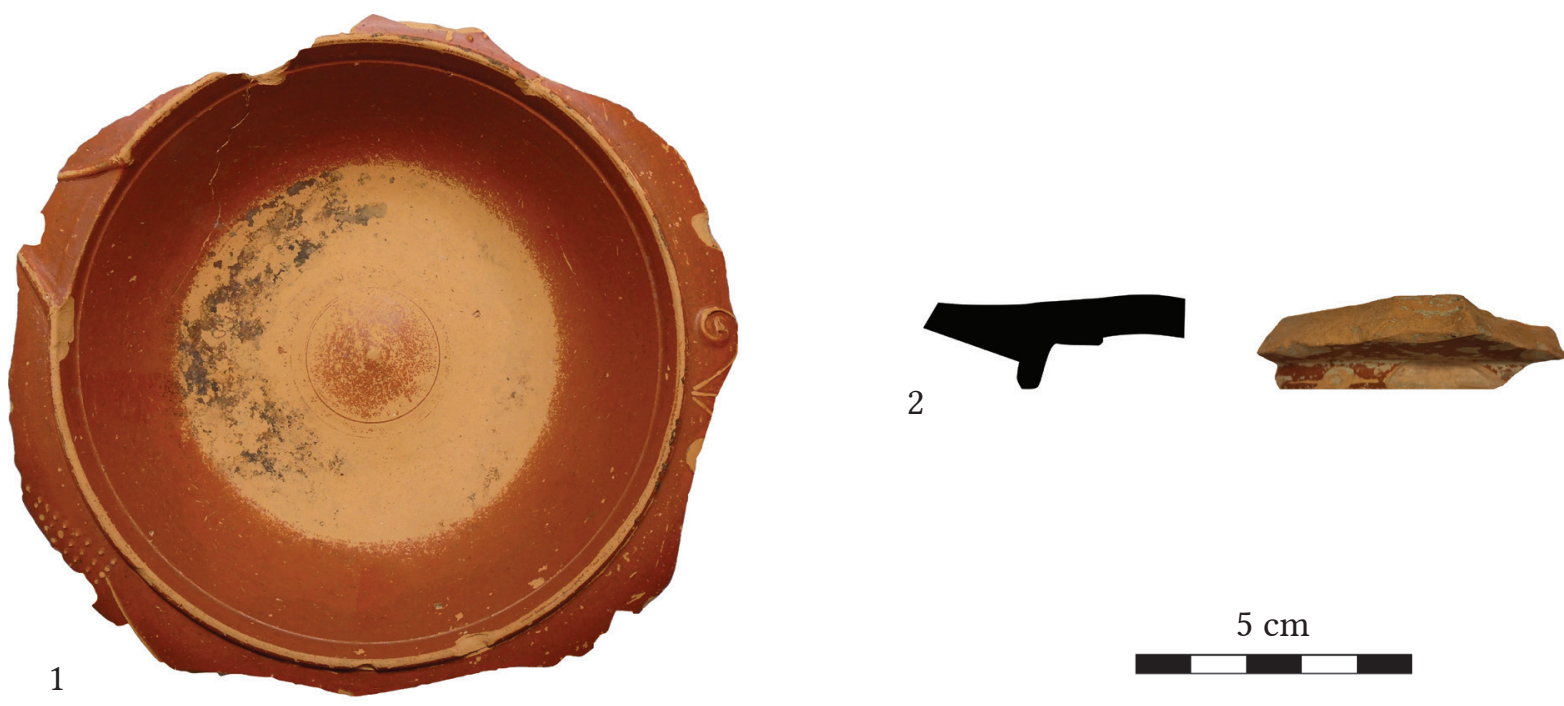

Fig. 3. Consp. 43 terra sigillata.

At first, South Gaulish wares were in a monopoly position in the Rhineland area, ${ }^{8}$ then became particularly popular on the Pannonian market very soon, at the turn of the $1^{\text {st }}$ and $2^{\text {nd }}$ century AD. A strong growth in the amount of South Gaulish terra sigillata can be observed after the rule of Trajan since that was the time when these wares started to take over the Italian vessels' place in the commerce along the Pannonian limes. ${ }^{9}$ The reason for this was that the South Gaulish workshops produced better quality terra sigillata and more importantly: the production and trasportation costs were much more lower due to the mass production..$^{10}$ The South Gaulish officinae were flourishing between the middle of the $1^{\text {st }}$ century and the first decades of the $2^{\text {nd }}$ century AD. ${ }^{11} \mathrm{~A}$ decrease in their export and the loss of the monopoly position in the area of the Rhine and the Danube can be dated to the $2^{\text {nd }}$ half of the $2^{\text {nd }}$ century. ${ }^{12}$
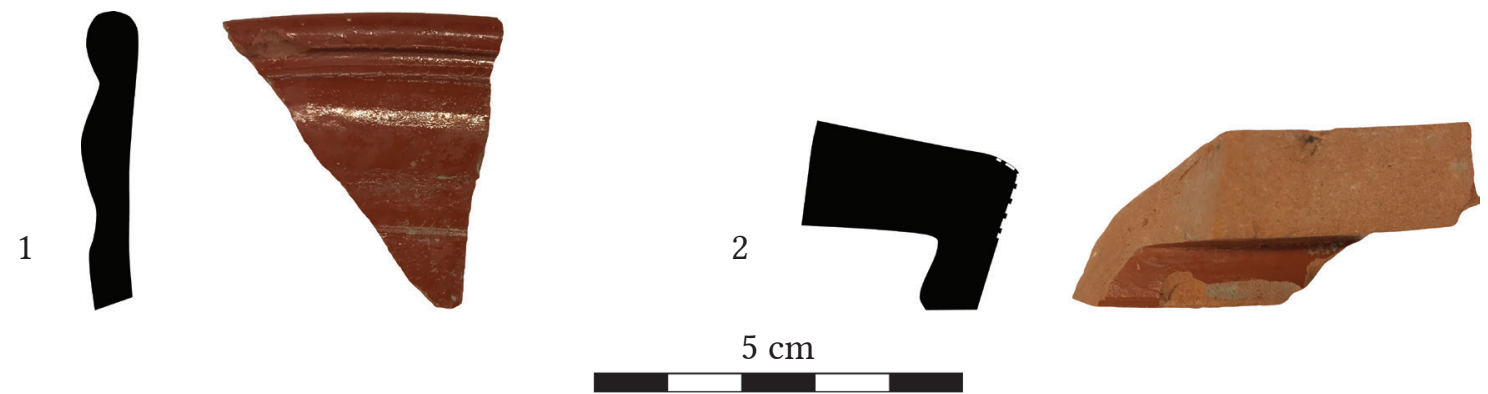

Fig. 4. South Gaulish Drag. 29 relief-decorated fragments.

Brigetio imported terra sigillata from the workshops of La Graufesenque and Banassac (52 sherds, 0.8\%) (Fig. 2). The researched material is consisting of relief-decorated bowls (Drag. 29 and 37) and various types of plain ware such as Drag. 18, 18/31, 31 and 32 plates, Drag. 27 and 33 cups as well as Drag. 35 and 36 dishes with barbotine-decorated rim.

12 MeEs 1995, 55. 
An interesting phenomenon in the examined assemblage is that some fragments of Drag. 29 relief-decorated bowls (Fig. 4) also occur in it. This vessel type is represented mainly on archaeological sites in the western part of Pannonia ${ }^{13}$ because the cost of transportation was lower to that area. It should be noted that in our province Drag. 29 bowls are uncommon, which can be explained by the fact that they were very expensive. It was clearly true for the trade of terra sigillata that where the population was wealthier, there was a larger the demand for the more special and more expensive products. For this reason, the presence of the Drag. 29 relief-decorated bowls - which were produced until the end of the $1^{\text {st }}$ century $y^{14}$ - indicates that the civil town of Brigetio was certainly flourishing and wealthy in the earliest period of its life.

The largest part of the South Gaulish relief-decorated bowls is consisting of fragments of the more common Drag. 37 form. This vessel type replaced the Drag. 29 bowls at the end of the $1^{\text {st }}$ century, around the years $85-90,{ }^{15}$ because it was easier and safer to transport.

\section{Central Gaulish terra sigillata}

The production of terra sigillata in Central Gaul already started at the beginning of the $1^{\text {st }}$ century $\mathrm{AD},{ }^{16}$ however its officinae exported their vessels in large quantities to Pannonia during the $2^{\text {nd }}$ century. Later the high-quality and carefully decorated Central Gaulish terra sigillata gradually came to the fore on the provinces' markets and in a short time it replaced the products of the other workshops.

Among the examined finds there are 1490 Central Gaulish sherds (22.87\%) (Fig. 2) which means that they are present in the material in the third largest proportion. The research clearly revealed that according to the attributable relief-decorations and the potters' namestamps, the Central Gaulish imports came exclusively from Lezoux. The intensive growth in the amount of terra sigillata shows that with the advancement of Romanization the everyday lifestyle and eating customs of the inhabitants of Brigetio changed as the expansion of the Roman culture involved, among others, the growth in the purchase of the Roman type vessels.

The economic prosperity of Pannonia - and, parallelly, of Brigetio - started around the middle of the $2^{\text {nd }}$ century, when the number of terra sigillata workshops has risen because of the growing demand for their products. According to the relief-decorated bowls and the plain wares bearing name-stamps among the examined finds, those Central Gaulish potters dominate who worked in Lezoux during the Antonine era especially between the years 120-200 AD.

A massive horizon composed of Cinnamus' wares can be observed in numerous archaeological sites in Pannonia. This phenomenon can be connected to the burnt destruction layers of the Marcomannic wars. In this regard, Brigetio is no exception either, this can be proved by the Central Gaulish terra sigillata finds of the civlilian town in which wares of Cinnamus dominate. ${ }^{17}$

13 For example, in the Pannonian capital Carnuntum which was situated in the western part of the province, some Drag. 29 relief-decorated bowls were revealed during the excavations (GABLER - GroH 2017, Tab. 2).

From Aquincum, the other important town in the province, however in its eastern area, this vessel type is also known (KabA 1963, 14. kép. 8; Mees 1993, Taf. 4. 1; Gabler 2012b, 119).

14 GABLER 2012b, 119.

15 GABLER 2012b, 119.

16 BÉMONT - JACOB 1986, 123.

17 BARtus et al. 2013, 36, 39-40; BARtus et al. 2016, 132-133. 

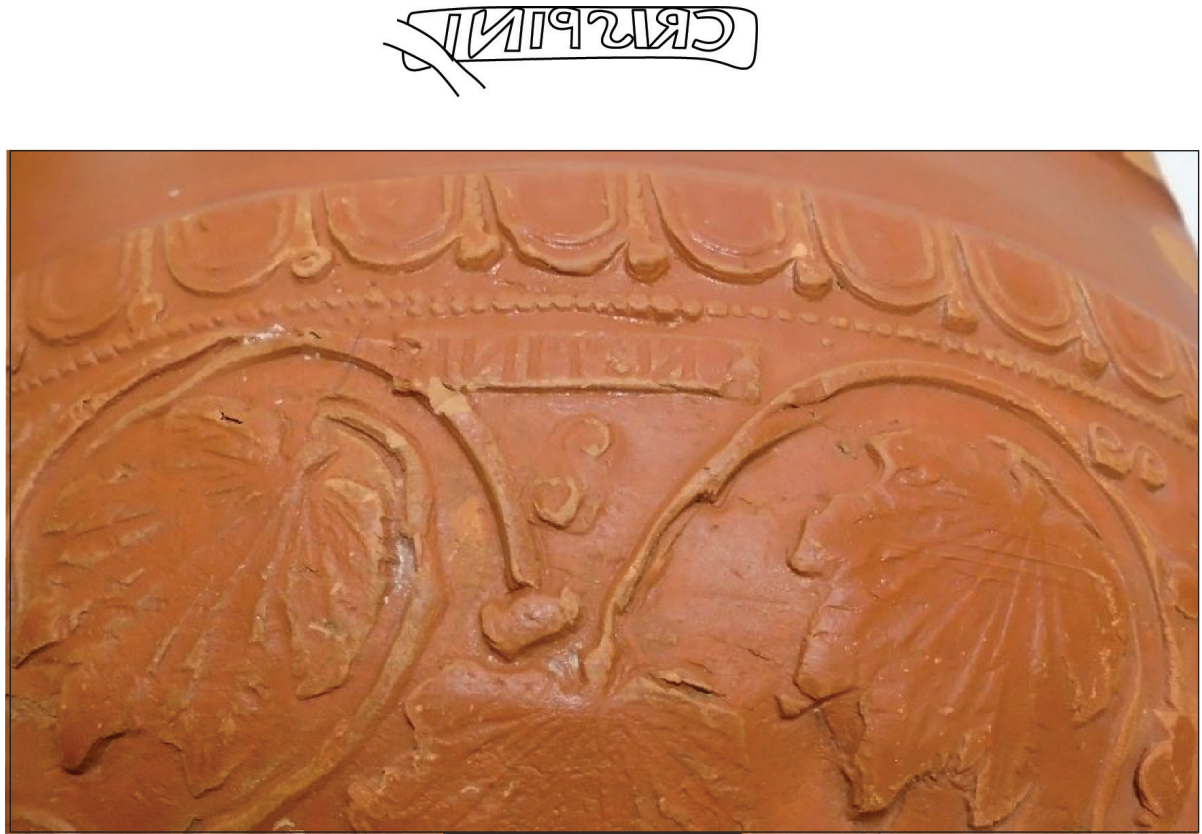

Fig. 5. Drag. 37 bowl from the workshop of Crispinus II.

Among the terra sigillata finds there is a relief-decorated bowl from Lezoux which sheds light on the connections between the manufactures of Central Gaul. This vessel was manufactured in the workshop of Crispinus II (160-200 AD) ${ }^{18}$ as its name-stamp shows. The bowl's uniqueness however is that its decoration, a naturalistic composition made of leaves and tendrils originates from a different officina, that of of Cettus who worked in Les Martres-de-Veyre (130-160 AD). ${ }^{19}$ The possible reason for this lies in the trade of moulds between potters. For example, in our case one of Cettus' moulds got to Lezoux from Les Martres-de-Veyre via commerce. In Lezoux Crispinus II made a new mould and stamped it with his name, which can be proved by the fading of the contours of the motives due to the shrinkage of the clay. Another reason is that one of the tendrils crosses the name-stamp which means that it was pressed to the mould first (Fig. 5). ${ }^{20}$

Beside the relief-decorated Drag. 30 and 37 bowls (Fig. 6), the Central Gaulish terra sigillata material shows the large variety of plain wares such as the Drag. 18, 31, 18/31 and 32 plate types; the Drag. 27 and 33 cups; the Drag. 38 mortariae and the Drag. 35 and 36 dishes with barbotine-decorated rim.

\section{East Gaulish terra sigillata}

The amount of the East Gaulish terra sigillata (5 sherds, 0.08\%) (Fig. 2) seems insignificant beside the other workshops' products however they are quite important, as their number in Pannonian archaeological contexts is low or they are missing completely. In the case of such a small amount from a certain manufacturing area, we should not exclude the possibility that the vessels did not only came via trade but they also 'wandered' with their owners.

20 BARtus et al. 2017, 104. 
In the eastern part of Gaul terra sigillata production started at the end of the $1^{\text {st }}$ century $A D$, around the Flavian era, when the limes was pushed forward. This resulted in the growth of the number of military troops in that area. Parallelly, the demand for terra sigillata vessels also grew. New, sparsely established and autonomously working officinae were organized to satisfy the increased purchase request. These workshops did not develop a homogeneous decoration style. ${ }^{21}$ The officinae were producing terra sigillata principally for themselves and for their close surroundings. Therefore the East Gaulish wares are uncommon in Pannonia, wheree the Central Gaulish terra sigillata dominated. ${ }^{22}$ By the time the workshops could develop themselves to export their products to farther provinces, the East Gaulish potters established new officinae in Germania, wares of which soon became popular along the Danube. For example, Ianuarius, Reginus and Verecundus were among thes potters who founded new workshops in Rheinzabern.

The few East Gaulish plain wares which were excavated in the civil town of Brigetio were exported from Heiligenberg and Ittenweiler in Alsace, according to their name-stamps. The workshops at Heiligenberg produced terra sigillata from Trajan's rule until the Antonine era. It was here that the potter Ianuarius started his career, who later founded a new officina in Rheinzabern. ${ }^{23}$ Ittenweiler was manufacturing terra sigillata during the Antonine era.
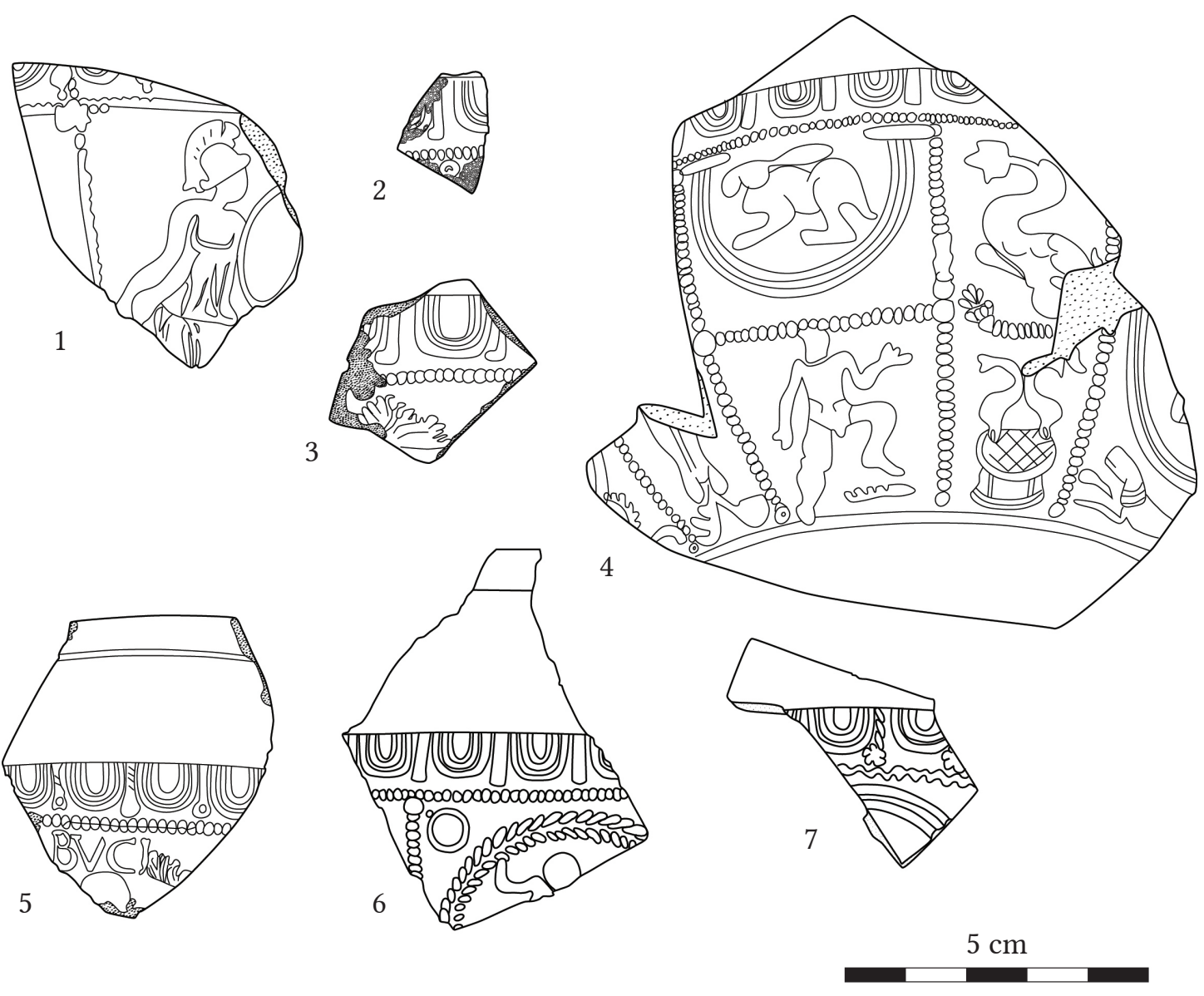

Fig. 6. Selection of the Central Gaulish Drag. 37 bowls.

23 BÉmont - Jacob 1986, 259; Mees 2002, 78; GnAde 2010, 226. 

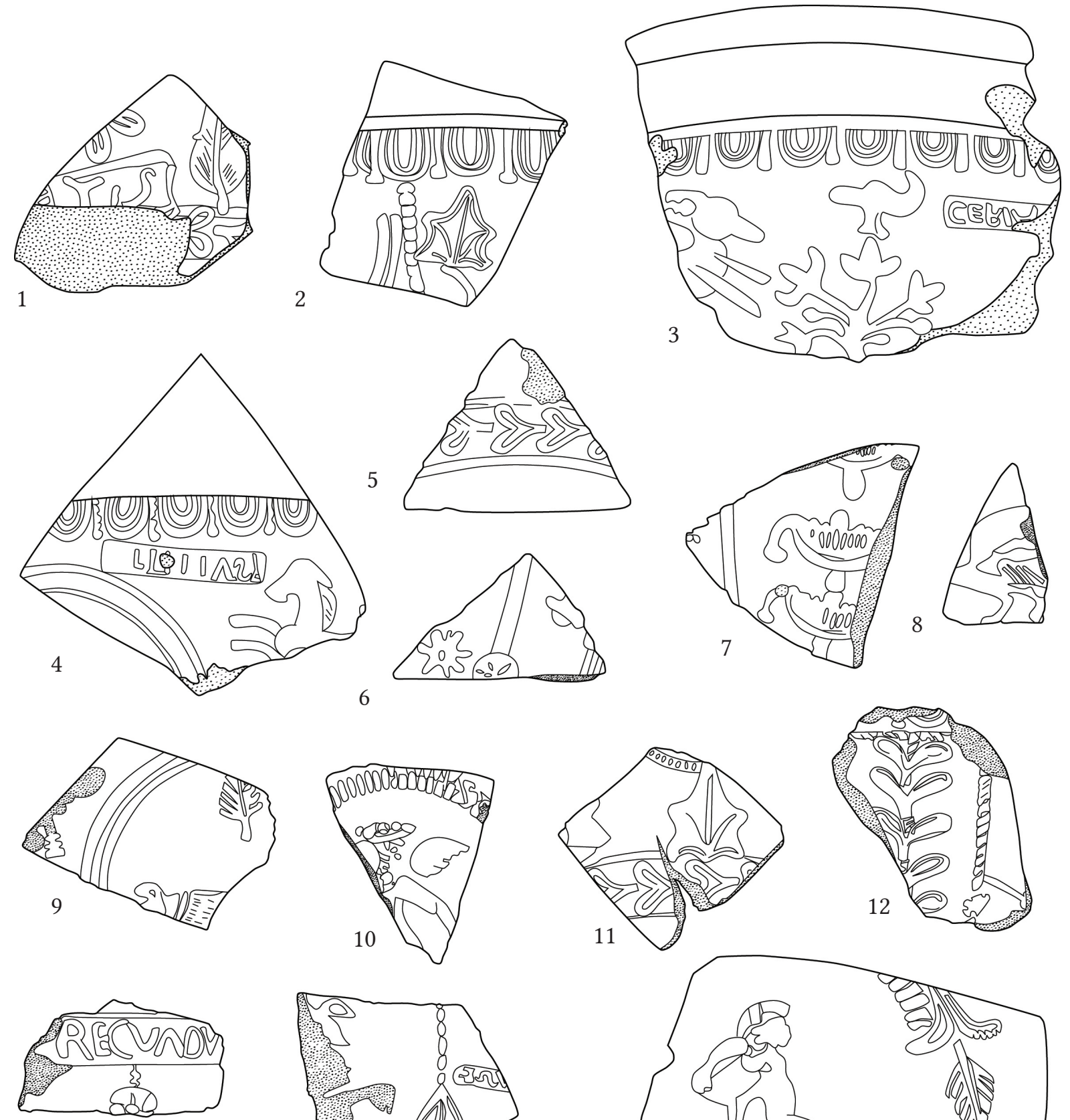

13
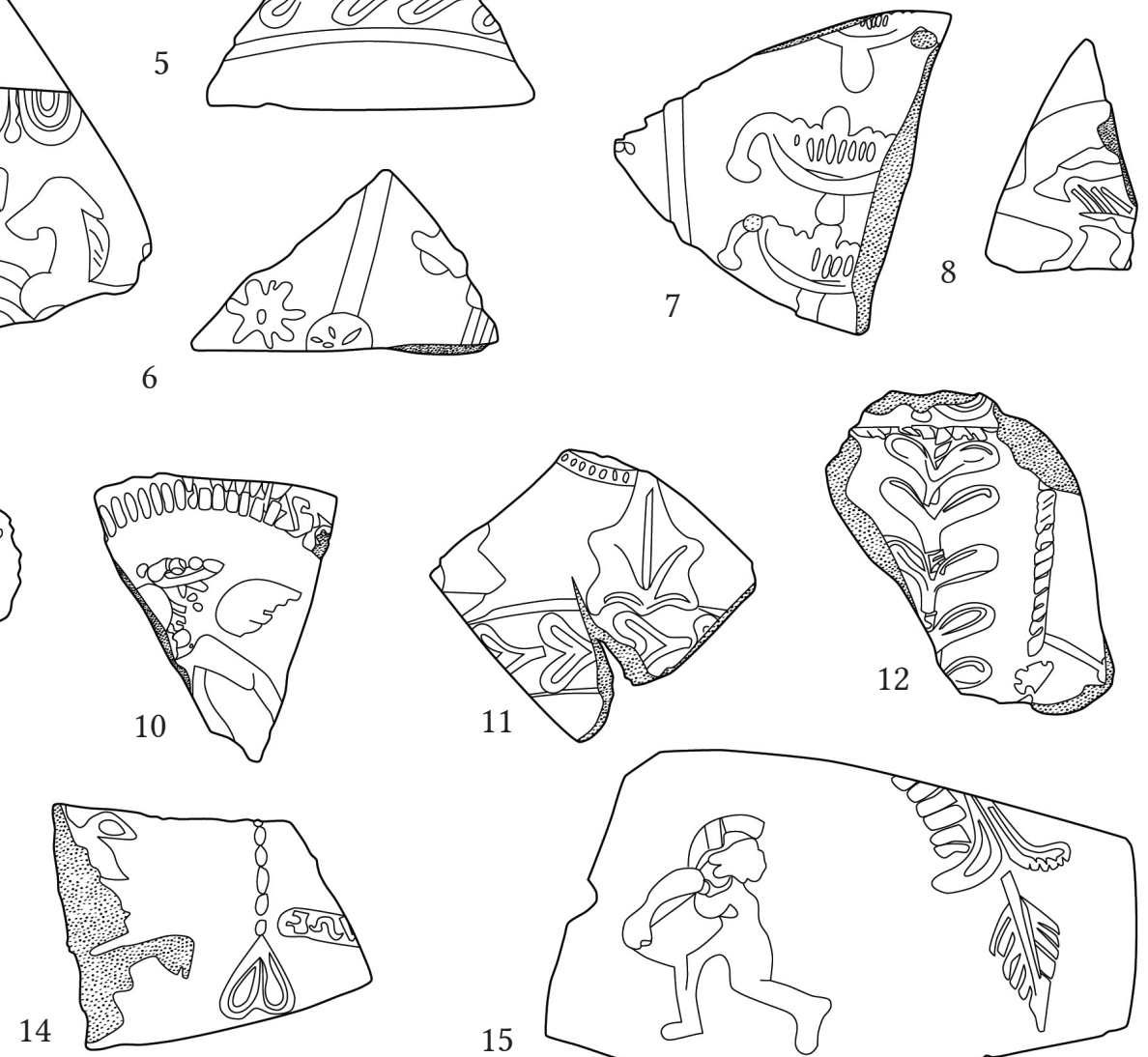

15
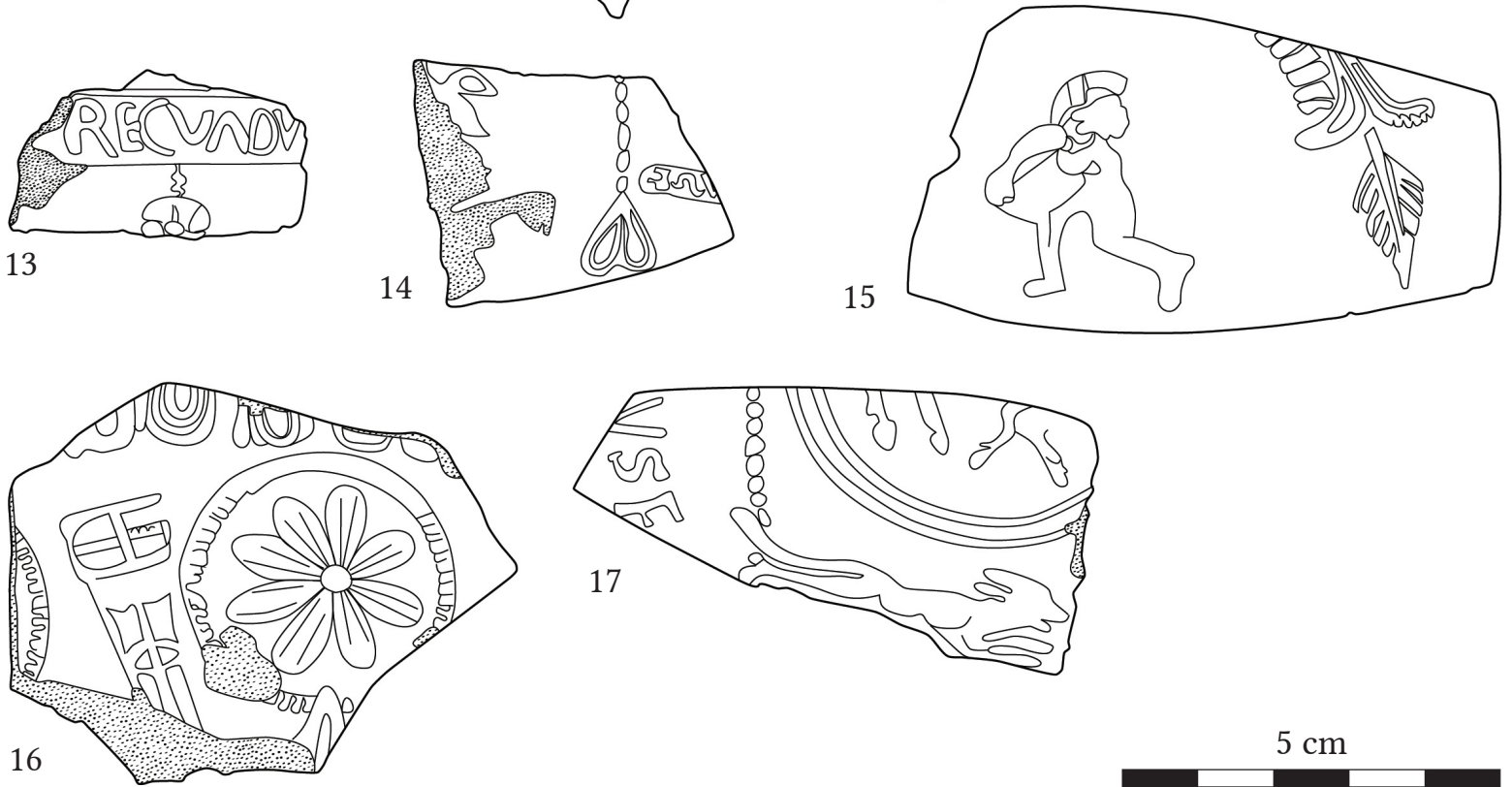

$5 \mathrm{~cm}$

Fig. 7. Selection of the Drag. 37 bowls form Rheinzabern. 


\section{Terra sigillata from Rheinzabern}

On the territory of modern Rheinzabern - is situated in the Roman province Germania Superior - the first terra sigillata workshop was founded around the years 155-160 by Ianuarius of the East Gaulish Heiligenberg. ${ }^{24}$ At that time the economy of the Empire was stable and the demand for terra sigillata was growing continuously, therefore it was necessary to establish a workshop which can produce vessels parallelly to Central Gaulish officinae. The closing date of Rheinzabern's workshops still poses a problematic question for researchers but they presumably ceased around the middle of the $3^{\text {rd }}$ century, between the years $260^{25}-270{ }^{26}$ Similarlyto other provinces along the Danube, in Pannonia the phenomenon can also be observedthat during the $2^{\text {nd }}$ century, terra sigillata import from Rheinzabern gradually came to the fore on the market and in short it replaced the Central Gaulish products completely.

Among the examined finds there are 2512 terra sigillata fragments from Rheinzabern (38.57\%) (Fig. 2) comprising the largest group. The vessels which are attributable to certain potter(s) or to their circle - are mostly made during the late Antonine or in the Severan era.

Besides the relief-decorated Drag. 30 and 37 bowls (Fig. 7), the terra sigillata imported from Rheinzabern shows a large variety of plain wares such as the Drag. 18, 31, 18/31, 32, 40, the Lud. Tb, Lud. Tf', Lud. Tl, the Curle 15 and Niederbieber 1 plate types; the Drag. 33 and 46 cups; the Drag. 38, 43 and 45 mortariae; the Drag. 39 platters and the Drag. 54 vessels with barbotine- and carved decoration.

It seems that Brigetio's terra sigillata consumption fell back for a few years during the $2^{\text {nd }}$ century due to the Marcomannic wars. This is suggested by the fact that the products of the potters active at that time are only represented by a few sherds or are absolutely missing from the find material.During the late Antonine era after the wars, economic consolidation began which brought success for the workshops of Rheinzabern and offered them a chance to satisfy the increasingly growing demand for terra sigillata. However, Rheinzabern only could not supply all costumers, therefore it seemed necessary to increase the number of officinae. This turned out to be a reasonable decision in light of the economic recovery during the forthcoming Severan era. In the middle $3^{\text {rd }}$ of the $3^{\text {rd }}$ century in Pannonia - similarly to other provinces along the Danube - the dominance of terra sigillata import from Rheinzabern started to decrease. ${ }^{27}$ The reason for this was the lower price of the vessels of Westerndorf and Pfaffenhofen, even though they were worse in quality and less aesthetic wares. The result was that the latter workshops came to the fore on the market due to the above-mentioned economical changesy.

\section{Terra sigillata from Westerndorf}

It is a widely known fact that the increasing export induced the establishment of the first manufacture in Westerndorf which was founded by Comitialis of Rheinzabern around the years $175-180 .{ }^{28}$ Not long after, Helenius joined him in Westerndorf and they were working

24 BÉmont - Jacob 1986, 259; Mees 2002, 78; Gnade 2010, 226; Gabler 2014, 76, 78.

25 MeEs 2002, 177-179; GABLER 2016, 137.

26 Gnade 2010, 242.

27 GABLER 2016, 139.

28 GABLER 1983, 354-355. 
parallelly to during the first half of the Severan era. From the end of this era until the $3^{\text {rd }}$ quarter of the $3^{\text {rd }}$ century, Onniorix succeeded them in Westerndorf. ${ }^{29}$

On the contrary to the earlier hypothesis, the manufactures of Westerndorf did not took the place of the ones at Rheinzabern but the officinae were helping each other to satisfy the costumers' growing demand for terra sigillata after the Marcomannic wars. The economic consolidation during the Severan era provided a niche in terra sigillata trade for both workshop areas. ${ }^{30}$ In addition, an interesting phenomenon can be observed: the wares produced in Westerndorf are more common along the limes than in the inner territory of Pannonia where the terra sigillata imported from Rheinzabern remained dominant during this period.

Among the examined terra sigillata finds there are 1606 terra sigillata sherds from Westerndorf (24.66\%) (Fig. 2), which means that they were present in the second largest proportion. At other Pannonian archaeological sites, similarly to the civil town of Brigetio, a tendency can be observed that vessels imported from Rheinzabern and Westerndorf. are dominant.

The most part of terra sigillata vessels imported from Westerndorf to the civil town of Brigetio were the relief-decorated Drag. 30 and 37 bowls (Fig. 8). In the less rich decoration of the Westerndorf wares the motives of Rheinzabern can be observed, which proves that the workshops were not rivals to each other. The lower price increased the popularity of Westerndorf products. In case of the civil town of Brigetio, among the terra sigillata import from Westerndorf the wares of Helenius ( $1^{\text {st }}$ half of the $3^{\text {rd }}$ century) dominate, similarly to other Pannonian settlements and towns. ${ }^{31}$ Besides the relief-decorated bowls there is a wide range of plain vessels such as the Drag. 18, 31, 18/31 and 32 plate types; and the Drag. 33 cups.

\section{Terra sigillata from Pfaffenhofen}

In relation to the terra sigillata findis from the civil town of Brigetio, the wares of Pfaffenhofen should also be mentioned, although they are only represented in smaller amounts (108 sherds, 1.66\%) (Fig. 2). The examined material is consisting of relief-decorated bowls (Drag. 30 and 37) and various types of plain wares such as the Drag. 18, 18/31, 31 and 32 type plates and 33 type cups.

In Pfaffenhofen, on the territory of the Roman Pons Aeni, the manufacture of terra sigillata started in the middle $3^{\text {rd }}$ of the $3^{\text {rd }}$ century ${ }^{32}$ when Helenius founded an officina there too, as production in Rheinzabern started to decrease ${ }^{33}$. The workshops at Westerndorf were already in decline at that time. After Helenius, another officina was established by Dicanus who moved to Pfaffenhofen from Trier. Among Brigetio's terra sigillata import from Pfaffenhofen, the circle of Dicanus (middle $3^{\text {rd }}$ of the $3^{\text {rd }}$ century) dominate.

The workshops at Pfaffenhofen ceased at the end of the middle $3^{\text {rd }}$ of the $3^{\text {rd }}$ century, around the years 260-270, due to the decline of the Rheinzabern officinae and the decrease in the export. $^{34}$

29 RAdBAuer 2013, 162.

30 Christlein et al. 1976, 79; Gabler 2012a, 436-437; Gabler 2012b, 122.

31 GABler 2012a, 437.

32 Christlein et al. 1976, 78-79.

33 GABler 2012a, 438.

34 Christlein et al. 1976, 79; Gabler 2014, 80. 

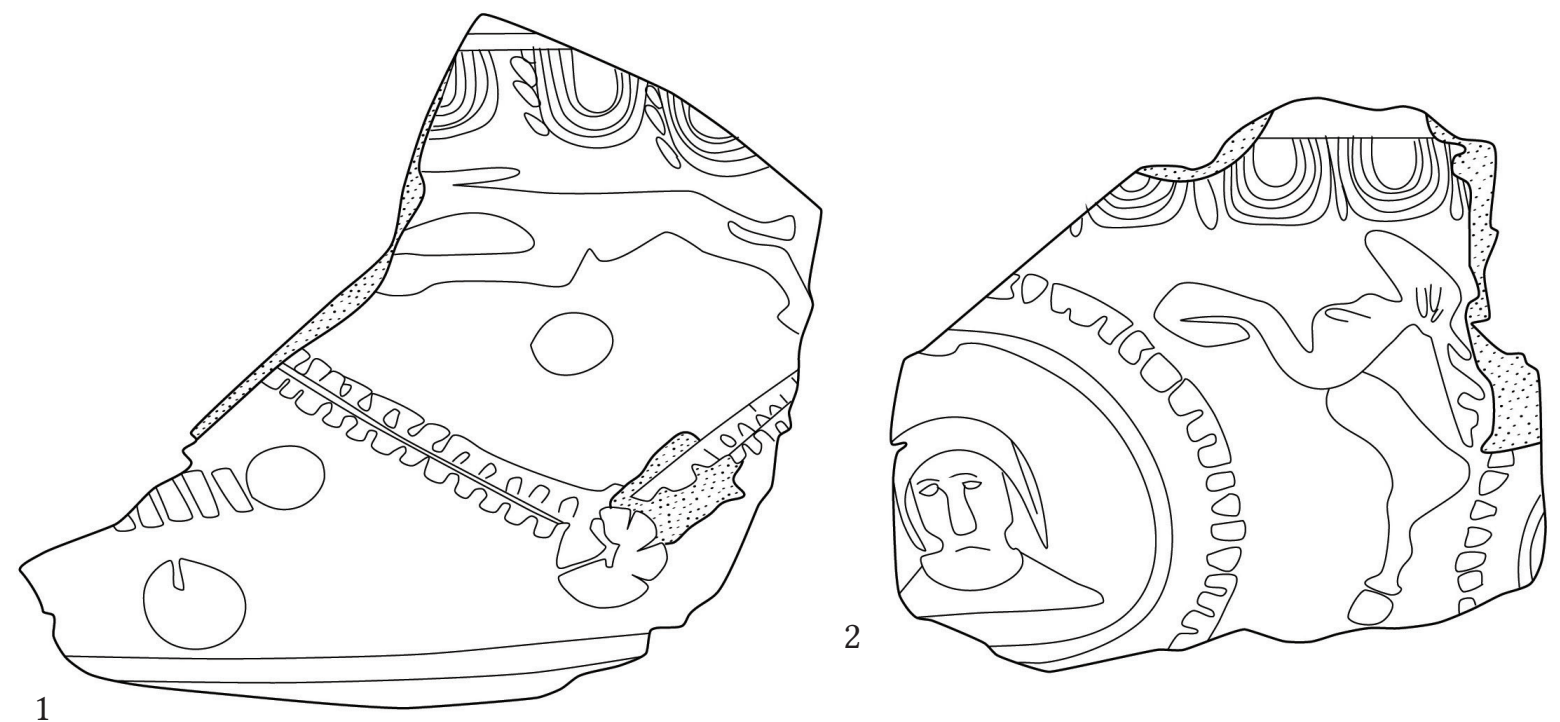

1
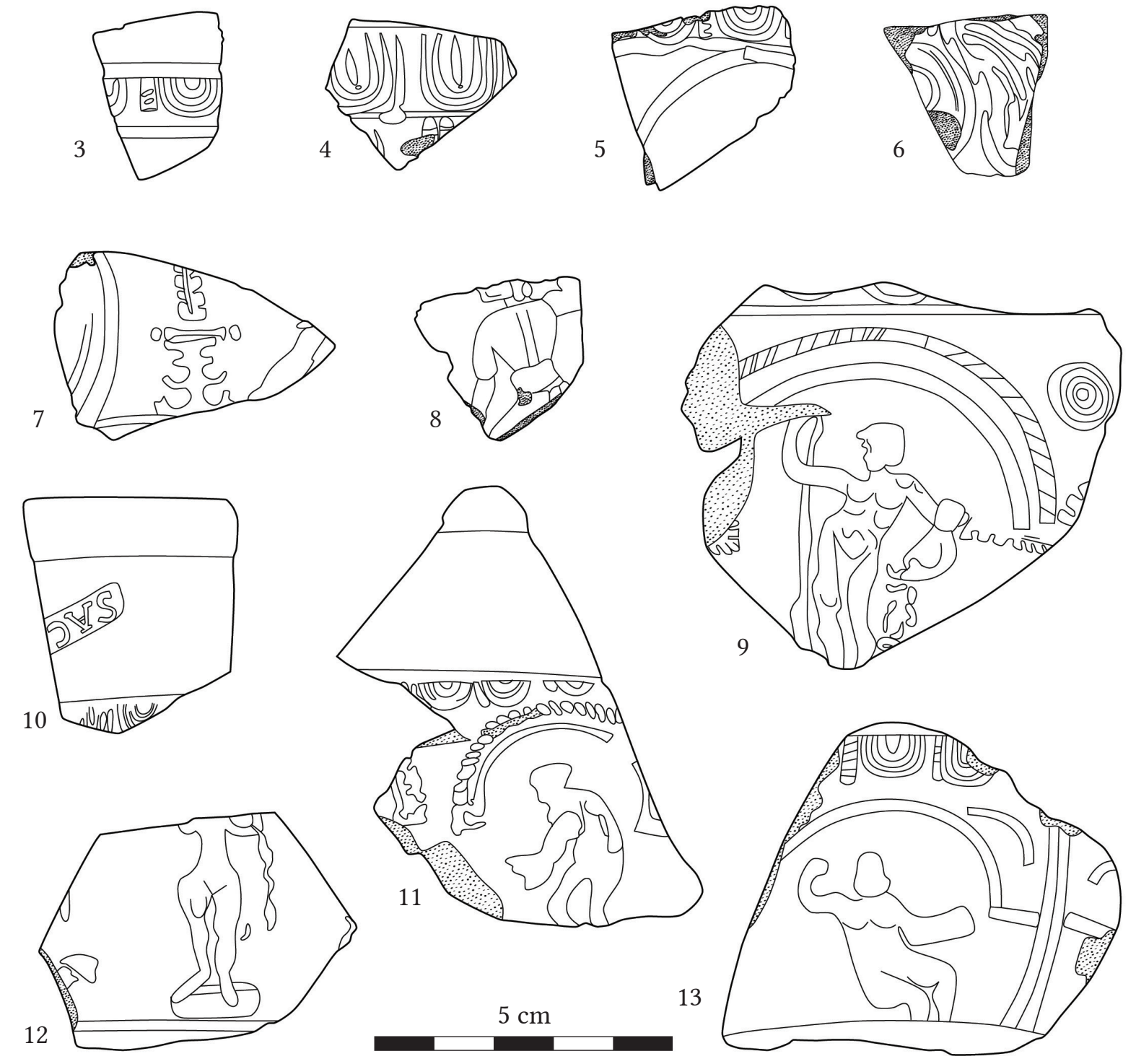

Fig. 8. Selection of the Drag. 37 bowls form Westerndorf. 


\section{North African red-slip wares}

Beyond the above-mentioned products, there are 2 sherds of terra sigillata (0.03\%) (Fig. 2) from the northern part of Africa, which signify the broadening of the commercial relationships of Brigetio. The amount of North African red-slip wares seems insignificant beside the products of other workshops, however they are quite important as their number is low in Pannonian archaeological contexts is or they are missing completely, especially in the northern part of the province.

The so-called 'terra sigillata chiara' or 'North African red-slip ware (ARSW)' spread after the decline of the workshops which manufactured relief-decorated wares. It became popular outside the Mediterranean territories of the Roman Empire during the $2^{\text {nd }}$ half of the $3^{\text {rd }}$ century. In the area of the Mediterranean Sea the ARSW was distributed since the $2^{\text {nd }}$ century. ${ }^{35}$

At first, North African red-slip wares copied the Italian and South Gaulish forms of dishes, plates and platters. The vessels are mostly plain wares, but they can be rouletted or decorated by stamps and applications. The motives which appear on the ARSW are mainly Christian symbols (for example fish, Christogram) or scenes from the Bible. The workshops in the middle part of Tunisia started to export the so-called 'chiara C' to Pannonia at the beginning of the $3^{\text {rd }}$ century, and the so-called 'chiara D' during the $4^{\text {th }}$ and $5^{\text {th }}$ centuries. ${ }^{36}$ Consequently, it is presumable that the ARSW fragments which were found in Brigetio were imported from one of these workshops.

North African red-slip wares occur principally on those archaeological sites which are situated in the western and southern part of Pannonia. ${ }^{37}$ This phenomenon can be connected to the Amber Road which played an important role in the African trade. The importance of the ARSW fragments from Brigetio lies in the fact that they came to light in archaeological context, while the context of other similar finds from the northern and eastern part of Pannonia is rarely known or missing totally. Therefore, it is very important to emphasize the presence of these few sherds. Moreover, by the African wares the decline of the civil town of Brigetio can be dated more precisely around the $4^{\text {th }}$ century.

The North African red-slip wares indicate that the Pannonian economy was going through changes at that time. Furthermore, they show a shift in commercial relationships because it seems that the provinces along the Danube got into closer contact with the Mediterranean in the $2^{\text {nd }}$ half of the $3^{\text {rd }}$ century and during the $4^{\text {th }}$ century. ${ }^{38}$

\section{Other perspectives of terra sigillata research}

During my research I have had the opportunity to use an Artec Spider blue light 3D scanner to scan a terra sigillata vessel found in the civil town of Brigetio. ${ }^{39}$ This scanner is useful for objects rich in detail, such as relief decorated terra sigillata bowls. The benefit of this device

39 I would like to express my gratitude to András Patay-Horváth (Department of Ancient History, ELTE) and Szilvia Joháczi (Department of Classical and Roman Archaeology, ELTE), for making the scanner available for my research and helping me during the scanning process. 
is that it not only records the shape of an object but also captures its texture. The digital model is very precise without any distortion and it can be rotated in 3D virtually. By this technology the smallest details can be observed on the surface.

With the help of the scanner, we digitalised a Drag. 37 form bowl from the material of the so-called ' $2{ }^{\text {nd }}$ cellar'. It was an almost completely restorable relief decorated vessel of Criciro's workshop (135\% $\left.140^{41}-165 \mathrm{AD}\right)$ at Lezoux (Fig. 9). The scanning of terra sigillata provides us the chance to study the decoration more precisely as it creates a non-stretchable model which is better than any drawing or photograph (Fig. 10). ${ }^{42}$

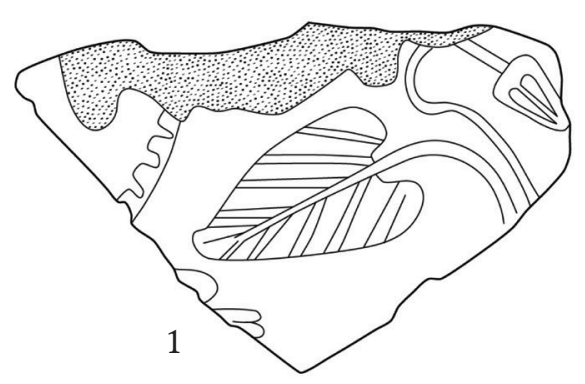

$5 \mathrm{~cm}$

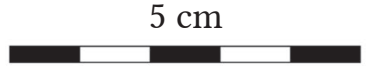

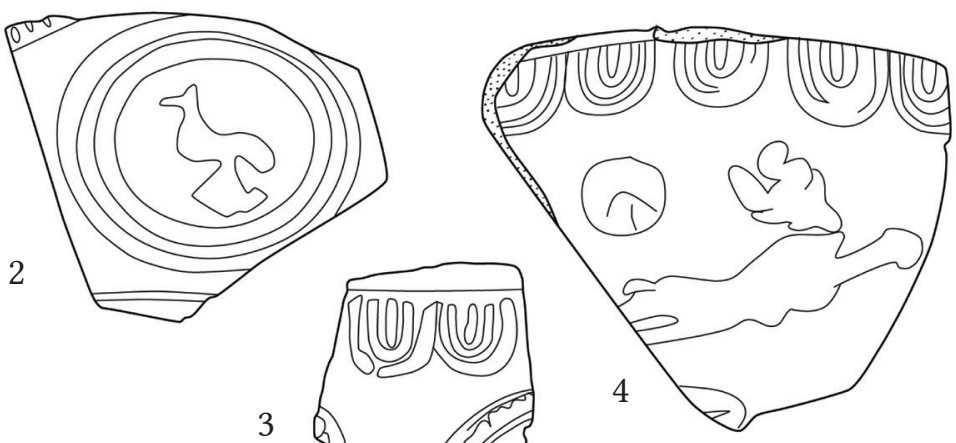

Fig. 9. Selection of the Drag. 37 bowls form Pfaffenhofen.

\section{Conclusion}

In summary the research of terra sigillata finds from the civil town of Brigetion revealed that the settlement had quite strong economic potential with far-reaching commercial relationships all across the Roman Empire. According to the terra sigillata finds, Brigetio had both periods of prosperity and declind, which were wavering throughout the history of the town. By the research of terra sigillata vessels a more precise overall picture unfolded of the life of Brigetio's civil town. The finds not only revealed the wide commercial relationships of Brigetio but also gave hints about the everyday life of its population. Additionally, the examination of terra sigillata sherds contributed important information about the dating of the buildings, workshops and other archeological features belonging to the civil town, valuable for future research.

40 GABler - MÁrton 2009, 240.

41 Simpson -STANField 1990, 252.

42 There are examples of the use of this technology among the international terra sigillata researchers. Allard W. Mees also applied a digital scanner for the tables in his monography about the South Gaulish workshops and potters (MEEs 1995). 

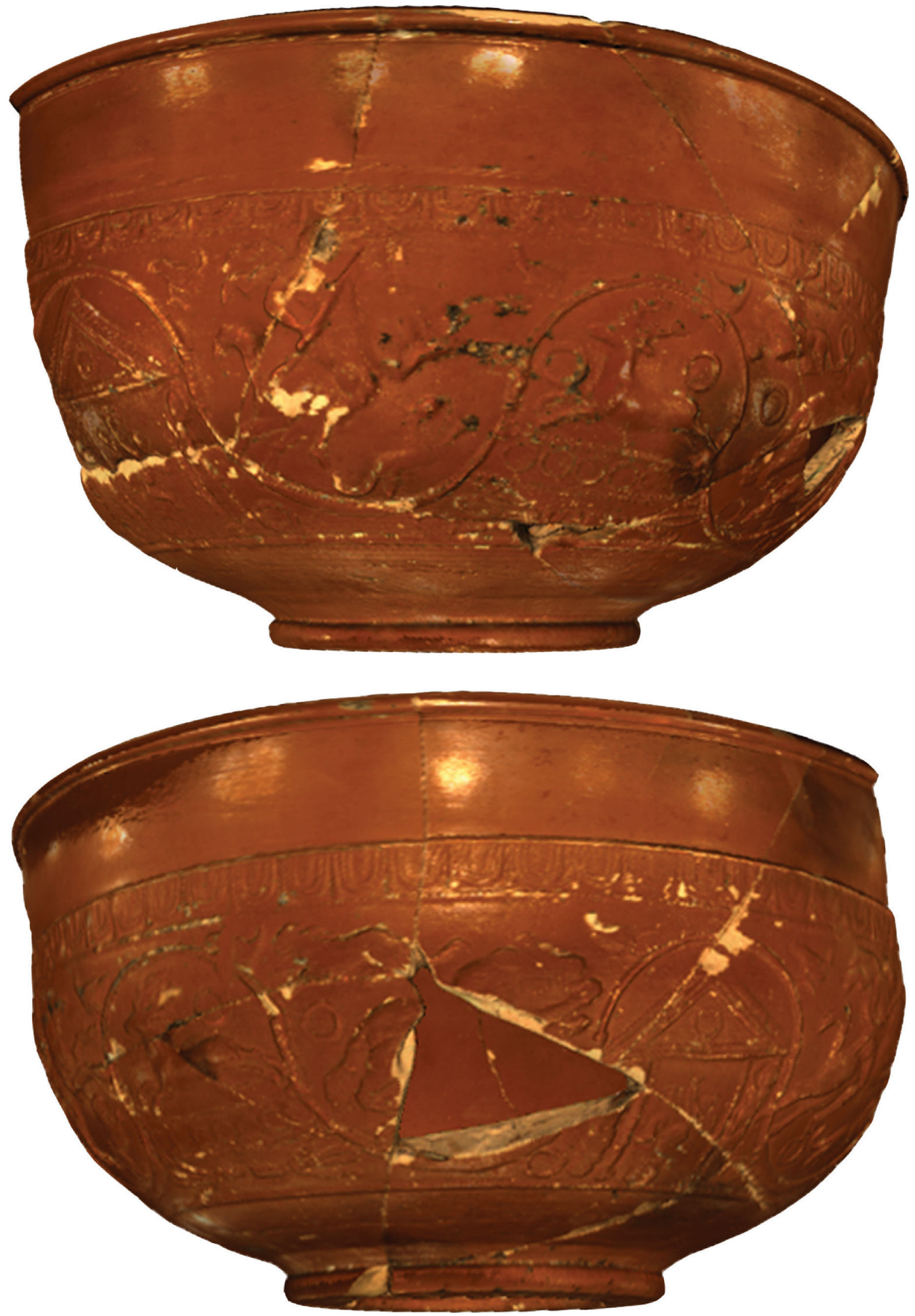

Fig. 10. Digital model of Criciro's Drag. 37 bowl. 
Terra sigillata from the territory of the civilian town of Brigetio

\begin{tabular}{|c|c|c|c|c|c|c|c|c|c|}
\hline & 2010 & 2011 & 2012 & 2013 & 2014 & 2015 & 2016 & Total & \\
\hline Northern Italy & 16 & 7 & 5 & 6 & 8 & 7 & 6 & 55 & $0.84 \%$ \\
\hline Southern Gaul & 7 & 9 & 6 & 13 & 0 & 7 & 10 & 52 & $0.8 \%$ \\
\hline Central Gaul & 515 & 215 & 193 & 213 & 139 & 137 & 78 & 1490 & $22.87 \%$ \\
\hline Gaul & 0 & 0 & 0 & 4 & 0 & 0 & 0 & 4 & $0.06 \%$ \\
\hline Eastern Gaul & 0 & 0 & 0 & 3 & 0 & 2 & 0 & 5 & $0.08 \%$ \\
\hline Rheinzabern & 552 & 656 & 359 & 372 & 374 & 159 & 40 & 2512 & $38.55 \%$ \\
\hline Westerndorf & 16 & 180 & 494 & 344 & 433 & 117 & 22 & 1606 & $24.65 \%$ \\
\hline Rheinzabern/Westerndorf & 0 & 100 & 53 & 139 & 92 & 37 & 21 & 442 & $6.78 \%$ \\
\hline Pfaffenhofen & 5 & 32 & 32 & 19 & 9 & 10 & 1 & 108 & $1.66 \%$ \\
\hline Westerndorf/Pfaffenhofen & 0 & 49 & 13 & 26 & 0 & 17 & 4 & 109 & $1.67 \%$ \\
\hline Northern Africa & 1 & 0 & 0 & 0 & 0 & 0 & 1 & 2 & $0.03 \%$ \\
\hline Unindentified & 1 & 101 & 2 & 20 & 4 & 0 & 3 & 131 & $2 \%$ \\
\hline Total & 1113 & 1349 & 1157 & 1159 & 1059 & 493 & 186 & 6516 & $100 \%$ \\
\hline
\end{tabular}

Tab. 1. Terra sigillata finds from the civil town of Brigetio according to the excavation seasons and the workshops.

\section{References}

Bartus, D. - Borhy, L. - Delbó, G. - Dévai, K. - Kis, Z. - Nagy, A. - Sey, N. - SzÁmadó, E. SzóRÁDI, Zs. - VIDA I. 2013: Jelentés a Komárom-Szőny, Vásártéren 2011-ben folytatott régészeti feltárások eredményeiről (Bericht über die Ergebnisse der im Jahre 2011 in Brigetio [FO: Komárom/Szőny, Vásártér] geführten archäologischen Ausgrabungen). Kuny Domokos Múzeum Közleményei 19, 9-94.

Bartus, D. - Borhy, L. - Delbó, G. - Dévai, K. - Juhász, L. - Hajdu, B. - Kis, Z. - Nagy, A. - Sáró, Cs. SEY, N. - SzÁmadó, E. 2016: Jelentés a Komárom-Szőny, Vásártéren 2014-ben folytatott régészeti feltárások eredményeiről (Bericht über die Ergebnisse der Jahre 2014 im Munizipium von Brigetio [FO: Komárom-Szőny, Vásártér] geführten archäologischen Grabungen). Kuny Domokos Múzeum Közleményei 22, 113-191.

Bartus, D. - Borhy, L. - Delbó, G. - Dévai, K. - Juhász, L. - Hajdu, B. - Kis, Z. - NAgy, A. - Sáró, Cs. SEY, N. - SzÁmadó, E. 2017: Jelentés a Komárom-Szőny, Vásártéren 2015-ben folytatott régészeti feltárások eredményeiről (Report on the excavations in the civil town of Komárom-Szőny, Vásártér [Brigetio] in 2015). Kuny Domokos Múzeum Közleményei 23, 83-153.

BÉmont, C. - JACOB, J.-P. 1986: La terre sigillée gallo-romaine. Lieux de production du Haut Empire: implantations, produits, relations. Documents d'Archéologie Française 6. Paris.

Christlein, R. - Czysz, W. - Garbsch, J. - Kellner, H.-J. - Schröter, P. 1976: Die Ausgrabungen 1969-1974 in Pons Aeni. Bayerische Vorgeschichtsblätter 41, 2-106.

Dickinson, B. M. - Hartley, B. R. 2008: Names on Terra Sigillata: An Index of Makers' Stamps \& Signatures on Gallo-Roman Terra Sigillata (Samian Ware). Volume 3 (CERTIANUS to EXSOBANO). London.

Ettlinger, E. - Hedinger, B. - Hoffmann, B. - Kenrick, P. M. - Pucci, G. - Roth-Rubi, K. - ScheiDer, G. - von Schnurbein, S. - Wells, C. M. - ZABehlicky-Scheffenegger, S. 2002: Conspectus Formarum Terrae Sigillatae Italico Modo Confectae. Materialen zur Römisch-Germanischen Keramik 10. Bonn.

Gabler, D. 1983: Die Westerndorfer Sigillata in Pannonien - Einige Besonderheiten ihrer Verbreitung. Jahrbuch des Römisch-Germanischen Zentralmuseums 30, 349-358. 
GABLER, D. 2001: A balácai terra sigillaták 3. Balácai Közlemények 6, 97-140.

GABLER, D. 2006: Terra Sigillata, a rómaiak luxuskerámiája. Budapest.

GABleR, D. 2012a: A budaörsi terra sigillaták. In: OtтомÁNyi, K. (eds.): Római vicus Budaörsön. Budapest, 409-453.

GABLER, D. 2012b: Terra sigillaták Aquincum legkorábbi táborából és annak helyén emelt későbbi római épületekből. Budapest Régiségei 45, 111-150.

GABleR, D. 2014: Terra Sigillaten in einem Luxusgebäude im nördlichen Teil der canabae von Aquincum (Budapest, III. Bez., Folyamőr-Straße). Schriften zur Archäologie und Archäometrie der Paris Lodron-Universität Salzburg 7, 71-87.

Gabler, D. 2016: Terra sigillaten in der Siedlung Visegrád-Lepence. Zborník Slovenského Národného Múzea, Archeológia Supplementum 11, 131-145.

Gabler, D. - Groh, S. 2017: Terra Sigillata aus den Zivilstädten von Carnuntum und Aquincum. Eine Analyse des Sigillata-Importes der Provinzhauptädte von Pannonia Superior et Inferior. Archäologische Forschungen in Niederösterreich, Neue Folge 4. Krems.

Gabler, D. - Márton, A. 2009: La circulation des sigillées en Pannonie d'après les estampilles sur sigillées lisses de Gaule, de Germanie et de la région danubienne. Revue Archéologique de l'Est $58,205-324$.

Gnade, B. 2010: Das römische Kastell Böhming am Raetischen Limes. Bericht der Bayerischen Bodendenkmalpflege 51, 199-285.

HeImerL, F. 2014: Nordafrikanische Sigillata, Küchenkeramik und Lampen aus Augusta Vindelicum/ Augsburg. Münchner Beiträge zur Provinzialrömischen Archäologie 6. Wiesbaden.

KABA, M. 1963: Római kori épületmaradványok a Király fürdőnél. Budapest Régiségei 20, 259-298.

MeEs, A. W. 1993: Probleme um die Anfangsdatierung von Aquincum. Budapest Régiségei 30, 61-85.

Mees, A. W. 1995: Modelsignierte Dekorationen auf südgallischer Terra Sigillata. Forschungen und Berichte zur Vor- und Frühgeschichte in Baden-Württemberg 54. Stuttgart.

MeEs, A. W. 2002: Organisationsformen römischer Töpfer-Manufakturen am Beispiel von Arezzo und Rheinzabern unter Berücksichtigung von Papyri, Inschriften und Rechtsquellen. Römisch-Germanischen Zentralmuseums Monographien 52. Mainz.

Radbauer, S. 2013: Die Terra Sigillata-Manufaktur von Westerndorf. Unpublished PhD thesis, Universität Wien.

Simpson, G. - Stanfield, J. A. 1990: Les potiers de la Gaule Centrale. Recherches sur les ateliers de potiers de la Gaule Centrale 5, Revue Archéologique Sites 37. Marseilles. 